\title{
Functional Properties of Linseed Meal Fractions: Application as Nutraceutical
}

\section{Ingredient}

\author{
Yumiko Yoshie-STARK ${ }^{1,2^{*}}$, Klaus MÜlLeR ${ }^{2}$, Hiroki KaWARAda ${ }^{3}$, Kazuyuki FutAGAwA ${ }^{3}$, Reiko NAKAda ${ }^{3}$ and \\ Yuri TASHIRO ${ }^{3}$ \\ ${ }^{1}$ Department of Life Sciences, Toyo University, 1-1-1 Izumino, Itakura, Oura, Gunma 374-0193, Japan \\ ${ }^{2}$ Department of Process Engineering, Fraunhofer Institute for Process Engineering and Packaging, Giggenhauserstrasse 35, Freising \\ 85352, Germany \\ ${ }^{3}$ Department of Food Science and Technology, Faculty of Marine Science, Tokyo University of Marine Science and Technology,4-5-7 Konan, \\ Minato, Tokyo 108-8477, Japan
}

Received January 21, 2011; Accepted March 3, 2011

Brown linseed (Linum ustatissimum) is pressed to produce oil, and the remaining linseed meal is rich in protein and soluble dietary fiber. To utilize the derivatives of linseed meal as food ingredients or additives, linseed meal was fractionated by controlling $\mathrm{pH}$ on a pilot-plant scale. Chemical composition, functional properties and health-related bioactivities, such as angiotensin-converting enzyme (ACE) inhibition and antioxidant activities, of the fractions were then analyzed. The alkaline soluble protein had the highest content of secoisolariciresinol diglucoside (SDG) and showed good emulsification activity, comparable to that of whole egg. The acid-soluble fraction showed the highest viscosity. ACE inhibition, antioxidant activities, and bile acid binding activity were observed in the soluble dietary fiber fraction. There was no correlation between SDG content and bioactivities. These findings indicate that the acid-soluble fraction is useful as a food ingredient to increase viscosity, while the soluble dietary fiber fraction has health-related features.

Keywords: Linum ustatissimum, fractionation, functional properties, hydrolysis, ACE inhibition, DPPH radical scavenging, $\mathrm{Cu}$ reduction, bile acid binding, LOX inhibition

\section{Introduction}

Linseed is useful for its oil, while the remaining material after oil extraction is rich in protein and viscous mucilage. Many researchers attempted to utilize whole linseed by fractionation; however, these purification methods are timeconsuming, expensive or decompose useful compounds such as phenolic acids (Chung et al., 2005, Oomah and Mazza, 1993, Oomah and Mazza, 1998). Interest in the use of whole linseed and its derivatives as functional foods or nutraceutical ingredients is still growing. Thus, we have attempted to fractionate de-oiled linseed using the simplest method possible. After establishing a simple fractionation method in preliminary experiments, it was necessary to further determine the functions and activities of each fraction in order to select

*To whom correspondence should be addressed.

E-mail: yumiko_y@toyo.jp the appropriate food application.

Physicochemical properties such as emulsification capacity and viscosity have provided ideas on how to apply linseed fractions to food processing. As in the case of lupin fractions (Yoshie-Stark et al., 2004), a protein-rich fraction may express angiotensin-converting enzyme (ACE) inhibitory activity after being converted to a peptide by gastrointestinal hydrolysis. Dietary fiber binds bile acids; therefore, a dietary-fiber-rich, viscous linseed fraction may exhibit bile acid binding and affect cholesterol metabolism in the human body (Wang et al., 2001).

In order to use linseed fractions for food applications, such fractions should not promote oxidation or induce spoliation. Therefore, the nonpromotion of lipid oxidation should be confirmed. It has been reported that lignans show certain health-related activities, and linseed is one of the richest sources of lignans (Westcott and Muir, 2003). The main 
lignan in linseed is secoisolariciresinol diglucoside (SDG), while phenolic compounds in linseed are coumaric acid and ferulic acid. They may also have health-promoting effects $(\mathrm{Hu}$ et al., 2007, Warrand et al., 2003).

Lignans are reported to lower the risk of cardiovascular diseases and to exhibit protective effects against breast cancer and colon cancer (Hall et al., 2006). The linseed lignan SDG was also shown to be effective as an antioxidant against DNA damage and lipid peroxidation (Westcott and Muir, 2003). The objectives of the present study were to determine the chemical composition and functional properties of linseed fractions as food ingredients, and to evaluate the healthrelated efficacy of these linseed fractions using various in vitro methodologies.

\section{Materials and Methods}

Materials Brown linseed (Linum usitassimum) was obtained from Thywissen GmbH, Germany. Linseed was pressed and oil was collected. After cold pressing, linseed meal was de-oiled using hexane. This de-oiled linseed meal was milled and used for the fractionation of protein and fibers on a pilot plant scale. ACE from rabbit lung was obtained from Sigma Chemicals Co. (St. Louis, MO), and bile acid analysis kit was obtained from Wako Pure Chemicals Co. (Osaka, Japan). All reagents used for experiments were of analytical grade.
Fractionation of de-oiled linseed meal Based on the report by Müller et al. (2010), fractionation using the pilotplant-scale method was optimized, as shown in Fig. 1. The acid-soluble fraction was further separated into the proteinrich fraction and carbohydrate-rich fraction; however, the acid-soluble fraction was not separated in this study because of low yield. De-oiled linseed meal was extracted under acidic conditions, and the acid-soluble fraction was then obtained. From the acid-insoluble residue, an alkaline-soluble protein fraction, and an alkaline soluble carbohydrate (soluble dietary fiber) fraction were prepared.

Proximate analysis The chemical composition (dry matter, nitrogen content, ash content, and oil content) of linseed, linseed meal, de-oiled linseed meal, and processed fractions were analyzed in accordance with standardized methods (Lebensmittel- und Bedarfsgegenstände-Gesetz, Methodenbeschreibungen,1995).

Analysis of molecular weight, sugar contents, sugar composition, and contents of phenolic compounds (SDG and hydroxycinnamic acid glucoside) The molecular weight of linseed meal fractions was analyzed by gel permeation chromatography. HPLC was performed on a Shodex Asahipak GS-510HQ column $(300 \mathrm{~mm} \times 7.6 \mathrm{~mm}$ i.d., Showa Denko Co., Tokyo, Japan) by elution with water at a flow rate of 1.0 $\mathrm{mL} \min ^{-1}$. Column temperature was set at $40^{\circ} \mathrm{C}$, and an $\mathrm{RI}$ detector was used. A pullulan (P-82, Showa Denko Co., To-

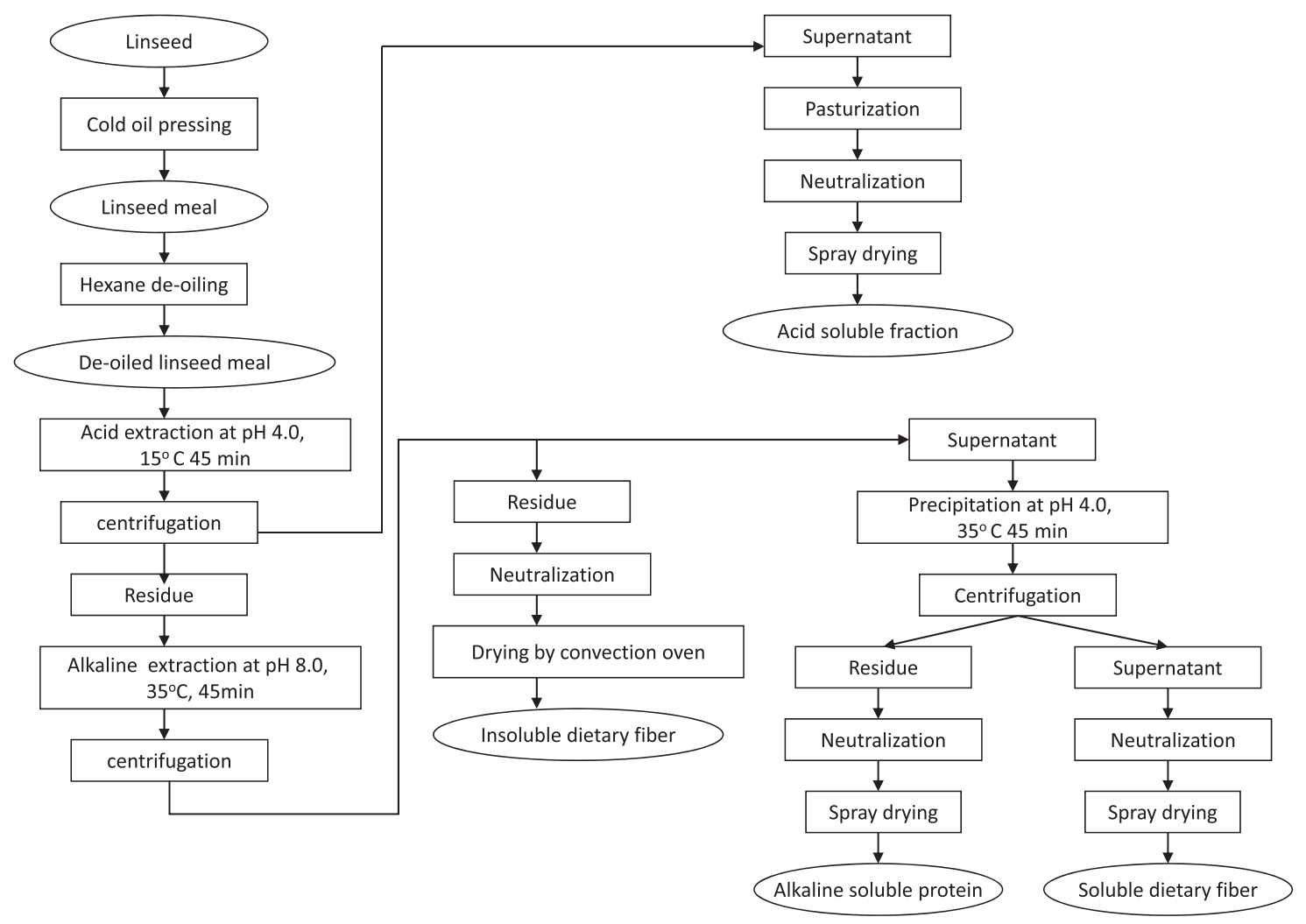

Fig. 1. General procedure for the fractionation of linseed meal in pilot plant scale. 
kyo, Japan) standard was used to evaluate molecular weight.

The total sugar content of linseed meal fractions (except the insoluble dietary fiber fraction) was determined by the phenol-sulfuric acid method using glucose as a standard (Dubois et al., 1956, Southgate, 1991). Total uronic acid content was determined by the method of Blumenkranz and AsboeHansen (1973) using galacturonic acid as a standard.

The acid soluble carbohydrate and soluble dietary fiber fractions were hydrolyzed with $2 \mathrm{~mol} / \mathrm{L}$ trifluoroacetic acid for $1 \mathrm{~h}$. Their monosaccharide composition was analyzed by HPLC using an Intertsil $\mathrm{NH}_{2}$ column $(250 \mathrm{~mm} \times 4.6 \mathrm{~mm}$ i.d., $5 \mu \mathrm{m}$, GL Science Co., Tokyo, Japan.) operated at $40^{\circ} \mathrm{C}$ and

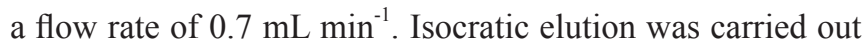
using acetonitrile/water $(75 / 25, \mathrm{v} / \mathrm{v})$ as a solvent. Components were detected using an RI detector, and were identified by comparison of their retention times with those of authentic standards under analysis conditions and quantified by the external standard method.

Phenolic compounds (SDG and hydroxycinnamic acid glucosides) in linseed fractions were extracted according to the method of Eliasson et al.(2003) and were analyzed by HPLC. Linseed fractions $(200 \mathrm{mg})$, vortexed together with $1.0 \mathrm{~mL}$ of an internal standard (o-coumaric acid, $0.8 \mathrm{mg} \mathrm{mL}^{-1}$ methanol), was continuously mixed with $4 \mathrm{~mL}$ of distilled water and $5 \mathrm{~mL}$ of $2 \mathrm{~mol} / \mathrm{L}$ aqueous sodium hydroxide for 1 $\mathrm{h}$ at $20^{\circ} \mathrm{C}$ by constant rotation. Hydrolysate was acidified to pH 3 using 2 mol/L sulfuric acid, and was centrifuged (1700 $\times \mathrm{g}, 10 \mathrm{~min})$. Supernatant was recentrifuged in microcentrifuge tubes $(11000 \times \mathrm{g}, 5 \mathrm{~min})$ to a clear liquid phase. The liquid phase $(0.6 \mathrm{~mL})$ was mixed with $95 \%$ aqueous ethanol $(0.9 \mathrm{~mL})$ in microcentrifuge tubes, allowed to stand at room temperature for at least $10 \mathrm{~min}$ and centrifuged $(11000 \times \mathrm{g}, 5$ $\mathrm{min}$ ) to precipitate and remove water-soluble polysaccharides and proteins. Before HPLC, a sample was filtered through $0.45 \mu \mathrm{m}$ cellulose acetate membrane. The sample solution was further subjected to HPLC using a TSK-GEL ODS$100 \mathrm{~V}$ column $(5 \mu \mathrm{m}, 150 \mathrm{~mm} \times 4.6 \mathrm{~mm}$, Tosoh, Japan) operated at $40^{\circ} \mathrm{C}$ and a flow rate of $1.0 \mathrm{~mL} \mathrm{~min}^{-1}$. Isocratic elution was performed with acetonitrile/ $0.1 \%$ phosphate $(75 / 25, \mathrm{v} / \mathrm{v})$ as a solvent. Components were detected using a diode array detector, and were identified by comparison of their retention times and spectra with those of authentic standards under analysis conditions. Recovery rate was calculated using an internal standard (o-coumaric acid) and was quantified by the external standard method.

Functional properties The functional properties of the linseed meal fractions were determined using standard methods. Protein solubility was determined at $\mathrm{pH} 7$ in accordance with the method of Morr et al. (1985), whereas the nitrogen solubility index (NSI) value was determined in accordance with the official AOCS (1998) or AACC methods (2000a). Water binding capacity analysis was conducted according to the AACC official method (2000b). Oil binding capacity was determined by dispersing the sample in oil and subsequent centrifugation according to the method described by Ludwig et al. (1989). Emulsification capacity and foaming activity were determined by the method of Yoshie-Stark et al. (2004).

Viscosity measurements Viscosity measurement was carried out using a Rheostress RS-50 rheometer (Haake, Karlsruhe, Germany). Linseed fractions were suspended at $5 \%(\mathrm{w} / \mathrm{v})$ in de-ionized water with stirring at $5^{\circ} \mathrm{C}$ for $18 \mathrm{~h}$. At a constant $\mathrm{pH} 7.00$, the effect of shear rate $\left(\mathrm{s}^{-1}\right)$ was evaluated.

Hydrolysis simulating gastrointestinal tract Simulation of gastrointestinal linseed hydrolysis was performed according to the method of Pihlanto-Leppälä et al. (1998) and Mullally et al. (1997), with the modifications reported by YoshieStark and Wäsche (2004). Methanolic extract was prepared for analysis of ACE inhibition, DPPH radical scavenging, copper reduction, LOX inhibitory activity, and bile acid binding capacity.

ACE inhibition ACE inhibitory activity was measured spectrophotometrically using hippuryl-L-histidyl-leucine (HHL) as a substrate, in accordance with the methods of Cushman and Cheung (1971) and Hernández-Ledesma et al. (2003), with the modifications reported by Yoshie-Stark et al. (2004). Captopril, which is used as a drug for inhibiting ACE activity, was also used in this study. Results were expressed as inhibition ratio (\%), and the most effective hydrolysate for inhibiting ACE was further analyzed in order to determine $\mathrm{IC}_{50}$ (concentration of samples required to inhibit $50 \%$ of ACE activity under given experimental conditions).

Lipoxygenase inhibition As described by Yoshie-Stark et al. (2009), LOX inhibitory activity was determined spectrophotometrically at room temperature by measuring the increase in absorbance at $234 \mathrm{~nm}$, and indicator of the oxidation of linoleic acid. The reaction mixture contained borate phosphate buffer (100 mmol/L, pH 9.0) with Tween $20(0.1 \%$, $\mathrm{v} / \mathrm{v})$, linoleic acid $(800 \mu \mathrm{mol} / \mathrm{L})$, an appropriate amount of methanolic extract from samples, and lipoxygenase from soybeans at a final concentration of 20 units $\mathrm{mL}^{-1}$. Results were expressed as $\mathrm{IC}_{50}$ (concentration of sample required to inhibit $50 \%$ of LOX activity under given experimental conditions).

1,1-diphenyl-2-picrylhydrazyl (DPPH) radical scavenging activity The method used to determine DPPH radical scavenging activity was based on the protocol of YoshieStark et al. (2004). Results are expressed as a median effective dose $\left(\mathrm{ED}_{50}\right.$; concentration of antioxidant required to quench $50 \%$ of initial DPPH radicals under given experi- 
mental conditions). Trolox, which is a strong DPPH radical scavenger, was also tested.

Antioxidant capacity based on copper reduction Total Antioxidant Capacity (TAC) Assay Kit (BioVision, Mountain View, CA) was used to determine copper reduction activity. Results were expressed as Trolox equivalent.

Bile acid binding Following the reports of Yoshie-Stark and Wäsche (2004) and Wang et al. (2001), bile acids (sodium cholate or sodium deoxycholate) were incubated with linseed fractions at $\mathrm{pH}$ 7. Bile acid was analyzed using a Wako Bile acid analysis kit (Wako Pure Chemicals Co.).

Statistical analysis Results are presented as mean values \pm S.D. ANOVA was carried out to determine significant differences (Steel and Torrie, 1980).

\section{Results and Discussion}

Yield of each fraction and chemical composition Dry matter and protein yields of each fraction and chemical composition of raw linseed to processed fractions are shown in Tables 1 and 2, respectively. The dry matter and protein yields of the insoluble dietary fiber fraction were both nearly $45 \%$, which indicates that approximately half of the linseed oil production waste was utilized. After the fractionation process, the alkaline-soluble protein fraction contained $71.1 \%$ protein, whereas the soluble dietary fiber fraction contained $32.3 \%$ protein. The alkaline-soluble protein fraction was well concentrated, and may thus be utilized as a protein source. The acid-soluble fraction was a mixture of protein and carbo- hydrate, containing $53.2 \%$ protein and $36.0 \%$ carbohydrate.

Molecular weight, sugar contents, sugar composition, and SDG contents The molecular weight and sugar contents of the linseed fractions are shown in Table 3. The main molecular weights of all linseed fractions ranged from 160,000 to 570,000 . Based on the viscosity measurement results shown in Fig. 2, it was assumed that the acid-soluble fraction had the highest viscosity, because of its high total sugar $(25.9 \%)$ and uronic acid (7.90\%) contents, not because of its molecular weight. The sugar compositions of the acidsoluble fraction and soluble dietary fiber fraction calculated as molar ratio of monosaccharide (\%) are shown in Table 4. Fedeniuk and Biliaderis (1994) reported that linseed mucilage (gum) contained fucose and galacturonic acid; however, this was not observed under our analysis conditions. The soluble dietary fiber fraction mainly consisted of arabinose (29.5\%), xylose $(21.1 \%)$, and glucose $(20.5 \%)$. This finding contrasted with the report of Warrand et al. (2003), who

Table 1. Mass and protein yield of the fractionation process.

\begin{tabular}{lcc}
\hline & $\begin{array}{c}\text { Dry matter yield } \\
(\%)\end{array}$ & $\begin{array}{c}\text { Protein yield } \\
(\%)\end{array}$ \\
\hline $\begin{array}{l}\text { Brown linseed meal } \\
\text { (hexane de-oiled) }\end{array}$ & 100 & 100 \\
Acid soluble fraction & 21.0 & 25.0 \\
Alkaline soluble protein & 14.0 & 16.0 \\
Soluble dietary fiber & 21.0 & 14.0 \\
Insoluble dietary fiber & 44.0 & 45.0 \\
\hline
\end{tabular}

Table 2. Chemical composition of linseed, linseed meal, de-oiled linseed meal, and processed fractions of linseed meal.

\begin{tabular}{lccccc} 
& & & & $(\mathrm{mean} \pm \mathrm{S} . \mathrm{D} ., \mathrm{n}=3)$ \\
\hline & Dry matter $(\%)$ & $\begin{array}{c}\text { Protein } \\
(\%, \text { per dry matter; DM) }\end{array}$ & $\begin{array}{c}\text { Ash } \\
(\%, \mathrm{DM})\end{array}$ & $\begin{array}{c}\text { Fat } \\
(\%, \mathrm{DM})\end{array}$ & $\begin{array}{c}\text { Carbohydrate } \\
(\%, \mathrm{DM})\end{array}$ \\
\hline Linseed (raw) & $92.6 \pm 0.41$ & $23.4 \pm 0.06$ & $3.50 \pm 0.10$ & $45.2 \pm 1.12$ & $27.8 \pm 1.08$ \\
Linseed meal & $87.4 \pm 0.28$ & $40.9 \pm 2.54$ & $6.30 \pm 0.85$ & $7.55 \pm 1.91$ & $45.3 \pm 1.48$ \\
Linseed meal & $90.3 \pm 2.21$ & $43.3 \pm 1.13$ & $6.40 \pm 0.03$ & $1.67 \pm 0.04$ & $48.7 \pm 1.14$ \\
(hexane de-oiled) & $95.1 \pm 0.08$ & $53.2 \pm 0.13$ & $9.64 \pm 0.58$ & $1.14 \pm 0.19$ & $36.0 \pm 1.18$ \\
Acid soluble fraction & $94.2 \pm 0.05$ & $71.1 \pm 0.15$ & $5.30 \pm 0.16$ & $2.10 \pm 0.19$ & $21.5 \pm 1.98$ \\
Alkaline soluble protein & $93.1 \pm 0.06$ & $32.3 \pm 0.01$ & $9.70 \pm 0.29$ & $0.60 \pm 0.08$ & $57.3 \pm 1.95$ \\
Soluble dietary fiber & $95.1 \pm 0.23$ & $47.0 \pm 0.21$ & $4.50 \pm 0.14$ & $2.00 \pm 0.04$ & $46.3 \pm 2.21$ \\
Insoluble dietary fiber & & &
\end{tabular}

Table 3. Molecular weight, total sugar content, and uronic acid content of processed fractions of linseed meal.

\begin{tabular}{lccc} 
& & $($ mean \pm S.D., $\mathrm{n}=3)$ \\
\hline Main molecular weight $\left(\times 10^{3}\right)$ & Total sugar $(\%)$ & Uronic acid (\%) \\
\hline Alkaline soluble protein & $570,470,160$ & $10.7 \pm 0.48^{\mathrm{a}}$ & $7.30 \pm 1.78^{\mathrm{b}}$ \\
Soluble dietary fiber & $570,470,270,170$ & $17.1 \pm 1.23^{\mathrm{b}}$ & $3.74 \pm 0.86^{\mathrm{a}}$ \\
Acid soluble fraction & $560,450,220$ & $25.9 \pm 7.00^{\mathrm{b}}$ & $7.90 \pm 2.00^{\mathrm{b}}$ \\
\hline
\end{tabular}




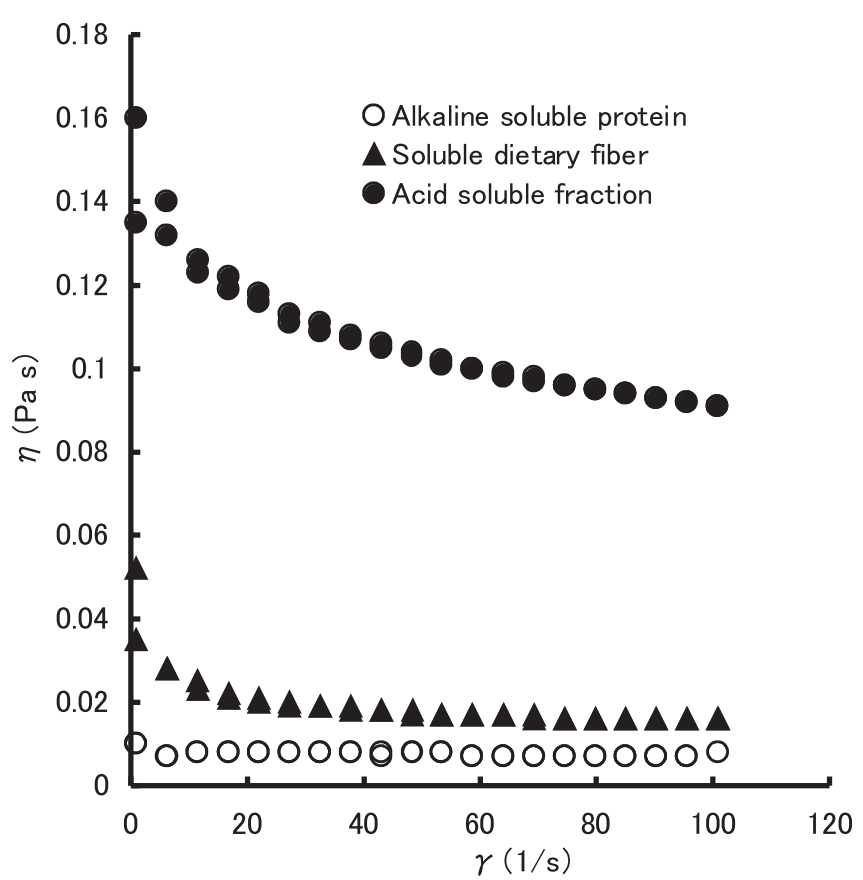

Fig. 2. Viscosity of linseed fractions. described the fractionation of linseed into two fractions; one mainly composed of xylose and glucose, the other composed mainly of galactose and arabinose. The acid-soluble fraction in this study contained rhamnose, xylose, arabinose, glucose and galactose, all of which showed contents of approximately $20 \%$ expressed as a molar ratio, and there was no significant difference in molar ratio among the sugars. The acid-soluble fraction showed significantly higher contents of rhamnose and galactose than the soluble dietary fiber fraction, whereas the soluble dietary fiber fraction showed a significantly higher arabinose content than the acid-soluble fraction.

Secosilariresinol diglucoside (SDG), coumaric acid, and ferulic acid were reportedly released from the lignan macromolecule after alkaline treatment (Eliasson et al., 2003). The contents of SDG, coumaric acid, and ferulic acid are shown in Table 5. The acid-soluble fraction contained significantly smaller amounts of SDG $\left(23.4 \mathrm{mg} \mathrm{g}^{-1}\right)$, coumaric acid $(0.087$ $\left.\mathrm{mg} \mathrm{g}^{-1}\right)$, and ferulic acid $\left(0.191 \mathrm{mg} \mathrm{g}^{-1}\right)$ than the alkaline-soluble protein. The alkaline-soluble protein fraction contained

Table 4. Relative monosaccharide composition of fractions of linseed meal.

\begin{tabular}{lccccc}
\hline & \multicolumn{5}{c}{ Sugar content (molar ratio, \%) } \\
\hline & Rhamnose & Xylose & Arabinose & Glucose & Galactose \\
\hline Acid soluble fraction & $19.7 \pm 4.37 \mathrm{~b}$ & $23.5 \pm 6.14 \mathrm{a}$ & $18.2 \pm 3.24 \mathrm{a}$ & $18.8 \pm 5.40 \mathrm{a}$ & $19.8 \pm 0.80 \mathrm{~b}$ \\
Soluble dietary fiber & $12.5 \pm 2.10 \mathrm{a}$ & $21.1 \pm 0.76 \mathrm{a}$ & $29.5 \pm 1.43 \mathrm{~b}$ & $20.5 \pm 1.21 \mathrm{a}$ & $16.4 \pm 0.38 \mathrm{a}$ \\
\hline
\end{tabular}

Table 5. SDG, coumaric acid, and ferulic acid contents in processed fractions of linseed meal and its methanol extracts.

$($ mean \pm S.D., $\mathrm{n}=3$ )

\begin{tabular}{|c|c|c|c|}
\hline & SDG & Coumaric acid & Ferulic acid \\
\hline \multicolumn{4}{|c|}{ Linseed fractions (phenolic compounds; $\mathrm{mg} \mathrm{g}^{-1} \mathrm{DM}$ ) } \\
\hline Acid soluble fraction & $23.4 \pm 1.86 \mathrm{a}$ & $0.087 \pm 0.004 \mathrm{a}$ & $0.191 \pm 0.011 \mathrm{a}$ \\
\hline Alkaline soluble protein & $163.8 \pm 14.6 \mathrm{c}$ & $0.894 \pm 0.057 \mathrm{c}$ & $1.966 \pm 0.128 b$ \\
\hline Soluble dietary fiber & $107.0 \pm 13.0 \mathrm{~b}$ & $0.465 \pm 0.118 b$ & $0.922 \pm 0.326 \mathrm{ab}$ \\
\hline \multicolumn{4}{|c|}{ Methanolic extracts (Linseed fractions (phenolic compounds; $\mu \mathrm{g} \mathrm{g}^{-1} \mathrm{DM}$ ) } \\
\hline Acid soluble fraction & - & $6.2 \pm 2.4 \mathrm{ab}$ & $9.3 \pm 1.7 \mathrm{ab}$ \\
\hline+ pepsin & - & $10.5 \pm 6.0 \mathrm{~b}$ & $17.8 \pm 7.8 \mathrm{c}$ \\
\hline+ pepsin/pancreatin & - & $7.4 \pm 1.4 \mathrm{~b}$ & $16.4 \pm 8.3 \mathrm{c}$ \\
\hline Alkaline soluble protein & - & $3.2 \pm 1.4 \mathrm{a}$ & $5.4 \pm 2.7 \mathrm{a}$ \\
\hline+ pepsin & - & $30.2 \pm 2.4 \mathrm{c}$ & $29.4 \pm 4.5 \mathrm{~d}$ \\
\hline+ pepsin/pancreatin & - & $29.7 \pm 9.5 \mathrm{c}$ & $22.4 \pm 6.5 \mathrm{~cd}$ \\
\hline Soluble dietary fiber & - & $9.7 \pm 1.7 b$ & $11.8 \pm 0.8 b c$ \\
\hline+ pepsin & - & $67.1 \pm 23.8 \mathrm{~d}$ & $65.7 \pm 13.7 \mathrm{e}$ \\
\hline+ pepsin/pancreatin & - & $48.6 \pm 17.5 \mathrm{~cd}$ & $51.3 \pm 10.6 \mathrm{e}$ \\
\hline
\end{tabular}

Different superscript letters within the same column of linseed fractions or methanolic extracts indicate significant differences at $\mathrm{p}<0.05$. 
significantly larger amounts of all three phenolic acids than the other fractions; the contents of SDG, coumaric acid, and ferulic acid were 163.8, 0.894, and $1.97 \mathrm{mg} \mathrm{g}^{-1}$ (dry sample), respectively. Eliasson et al. (2003) reported that the contents of SDG, coumaric acid, and ferulic acid in linseed are 11-26, 1.2-8.5, and 1.6-5.0 $\mathrm{mg} \mathrm{g}^{-1}$ (dry sample), respectively. Strandas et al. (2008) reported that the content of SDG of de-oiled linseed is $38.5 \mathrm{mg} \mathrm{g}^{-1}$ (dry sample). When compared with these reports, the alkaline-soluble protein and soluble dietary fiber fractions in this study showed higher amounts of SDG, but much smaller amounts of coumaric and ferulic acids.

Physicochemical properties of fractions Viscosity of a $5 \%(\mathrm{w} / \mathrm{v})$ suspension of linseed fractions was found to be in the 0.01-0.16 Pa s range, as shown in Fig. 2.

The acid-soluble fraction with a carbohydrate content of $36.0 \%$ showed the highest viscosity among the fractions. Soluble dietary fiber contained $57.3 \%$ carbohydrate; however, it did not show a high viscosity. When linseed gum (soluble dietary fiber $=$ polysaccharide) was extracted under optimized conditions reported by Cui et al. (1994) and Warrand et al. (2003), that gum solution $(2 \%, \mathrm{w} / \mathrm{w})$ showed viscosities of 0.06 and $0.2 \mathrm{~Pa} \mathrm{~s}$ at $\mathrm{r}=50 \mathrm{~s}^{-1}$, respectively. The soluble dietary fiber and acid-soluble protein fractions showed viscosities of 0.02 and $0.1 \mathrm{~Pa} \mathrm{~s}$ at $\mathrm{r}=50 \mathrm{~s}^{-1}$, respectively. However, a $5 \%$ solution of the acid-soluble protein fraction, not the gum (soluble dietary fiber)-rich fraction, showed a viscosity approximately twice $(0.11 \mathrm{~Pa} \mathrm{~s})$ that of a $2 \%$ solution of linseed gum reported by $\mathrm{Cu}$ et al. (0.06 Pa s) (1994). With regard to the $36 \%$ carbohydrate content in the acid-soluble protein fraction, viscous soluble dietary fiber may have been extracted effectively into the acid-soluble fraction.

Functional properties of each fraction are shown in Table 6 . The protein solubility of linseed alkaline-soluble protein was $48.0 \%$, and this was lower than egg (65.0\%; YoshieStark et al., 2004) but similar to a commercial soy protein isolate $(45.0 \%)$. The water binding capacity of both insoluble dietary fiber fractions was highest $\left(6.70 \mathrm{ml} \mathrm{g}^{-1}\right)$. The oil binding capacity of insoluble dietary fiber was higher than that of the commercial soy protein isolate $\left(1.8 \mathrm{ml} \mathrm{g}^{-1}\right)$, but the oil binding capacity of soluble dietary fiber was similar (1.60 $\mathrm{ml} \mathrm{g}^{-1}$ ) to that of the soy protein isolate. Some reports have found the water binding capacity of linseed mucilage to be in the range of $16-30 \mathrm{~g} \mathrm{H}_{2} \mathrm{O} \mathrm{g}^{-1}$ (Fedeniuk and Biliaderis, 1994) and the oil binding capacity of linseed protein isolate to be $0.93 \mathrm{ml} \mathrm{g}^{-1}$ (Wanasundara and Shahidi, 1997). When compared with the report on pure linseed mucilage, our results showed a considerably lower water binding capacity; however, all linseed fractions showed a higher oil binding capacity than the linseed protein isolate prepared by another method (Wanasundara and Shahidi, 1997). The linseed alkaline-soluble protein showed an emulsification capacity of up to $535 \mathrm{ml} \mathrm{g}^{-1}$, which was higher than that of whole egg (495 $\mathrm{ml} \mathrm{g}^{-1}$, Yoshie-Stark et al., 2004), and lower than that of egg white $\left(800 \mathrm{ml} \mathrm{g}^{-1}\right)$. Linseed alkaline-soluble protein and soluble dietary fiber showed foaming activities of $1650 \%$ and $1510 \%$, respectively. The hexane de-oiled commercial linseed meal and linseed protein isolate were reported to have foaming capacities of 59.2\% (Oomah and Mazza, 1993), and $112 \%$ (Wanasundara and Shahidi, 1997), respectively. In comparison with these reports, our protein fractions showed higher foaming activities. This finding indicates effective fractionation with useful functional properties as food stabilizer or emulsifier.

Physiological function of fractions Methanolic extracts were used to evaluate ACE inhibition, DPPH radical scavenging activity, copper reducing capacity, LOX inhibition, and bile acid binding capacity. As shown in Table 5, none of the tested methanolic extracts contained SDG; they contained coumaric and ferulic acids. Methanol did not extract SDG effectively, instead, we believe that a certain percentage of free amino acids and peptides was produced by in vitro hydrolysis and this was extracted by methanol.

ACE was inhibited only by the soluble dietary fiber fraction; as shown in Fig. 3 (top). Pepsin hydrolysate of the soluble dietary fiber fraction including $0.067 \mathrm{mg} / \mathrm{g}$ coumaric acid and $0.066 \mathrm{mg} / \mathrm{g}$ ferulic acid showed the highest ACE inhibi-

Table 6. SDG, coumaric acid, and ferulic acid contents in processed fractions of linseed meal and its methanol extracts.

\begin{tabular}{|c|c|c|c|c|c|}
\hline & $\begin{array}{c}\text { Protein solubility } \\
\text { at pH } 7(\%)\end{array}$ & $\begin{array}{l}\text { Water binding } \\
(\mathrm{ml} / \mathrm{g})\end{array}$ & $\begin{array}{l}\text { Oil binding } \\
\quad(\mathrm{ml} / \mathrm{g})\end{array}$ & $\begin{array}{l}\text { Emulsification } \\
\text { capacity }(\mathrm{ml} / \mathrm{g})\end{array}$ & $\underset{(\%)}{\text { Foaming activity }}$ \\
\hline Acid soluble fraction & N.A. & $5.2 \pm 0.35 c$ & $1.80 \pm 0.11 \mathrm{a}$ & $335 \pm 15.0 b$ & $563 \pm 44.7 a$ \\
\hline Alkaline soluble protein & $48.0 \pm 0.28 \mathrm{a}$ & $0.80 \pm 0.05 a$ & $2.50 \pm 0.05 b$ & $535 \pm 31.0 \mathrm{c}$ & $1650 \pm 43.5 c$ \\
\hline Soluble dietary fiber & N.A. & 0 & $1.60 \pm 0.07 \mathrm{a}$ & $145 \pm 6.50 \mathrm{a}$ & $1510 \pm 72.3 c$ \\
\hline Insoluble dietary fiber & N.A. & $6.70 \pm 0.35 \mathrm{~d}$ & $3.70 \pm 0.08 \mathrm{c}$ & N.A. & N.A. \\
\hline Soy protein isolate & $45.0 \pm 0.27 \mathrm{a}$ & $1.9 \pm 0.13 b$ & $1.8 \pm 0.08 \mathrm{a}$ & $605 \pm 27.2 \mathrm{c}$ & $900 \pm 43.0 b$ \\
\hline
\end{tabular}

Different superscript letters within the same column indicate significant differences at $\mathrm{p}<0.05$. 

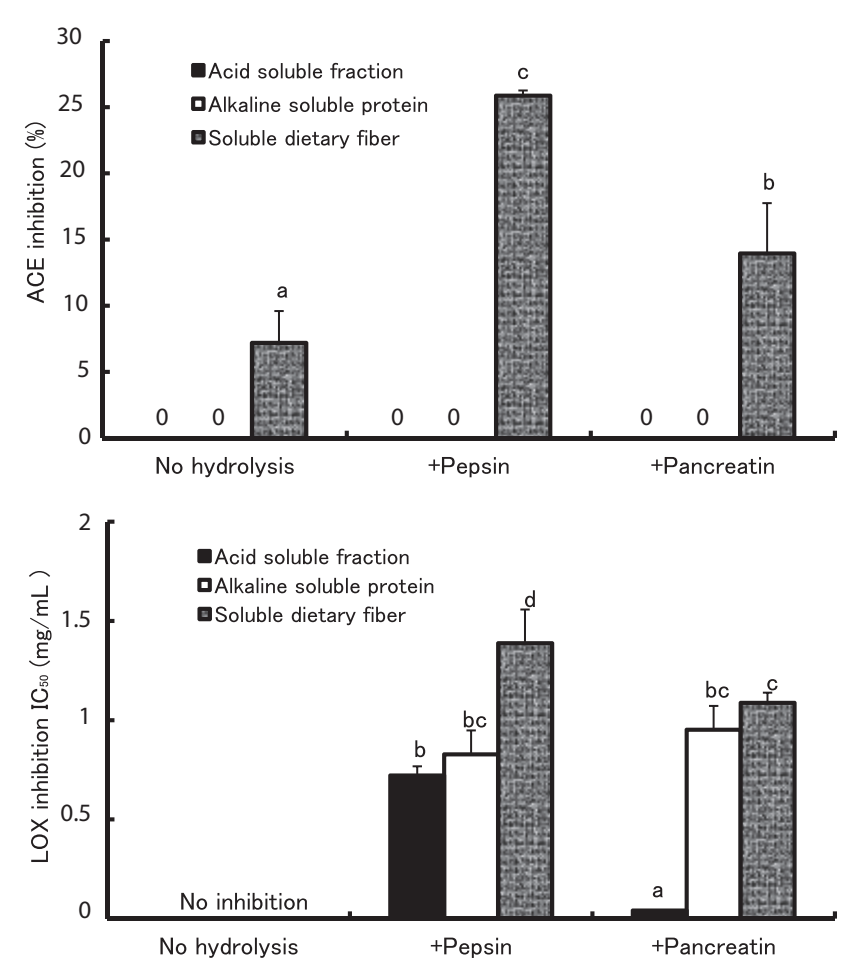

Fig. 3. ACE inhibitory (top) and LOX inhibitory (bottom) activities of linseed fractions and its hydrolysates. Different letters within the same figure indicate significant differences at $\mathrm{p}<0.05$.

tion. These hydroxycinnamic acid contents were the highest among all the tested extracts. When further experiments were performed to obtain the concentration inhibiting $50 \%$ of ACE activity, the pepsin-hydrolyzed soluble dietary fiber showed an $\mathrm{IC}_{50}$ of $23.9 \mathrm{mg} \mathrm{ml}^{-1}$, whereas captopril showed an $\mathrm{IC}_{50}$ of $3.09 \mathrm{ng}$ ml-1. Ugenigwe et al. (2009a) reported that, with regard to the ACE inhibitory activities of flaxseed protein pepsin or pancreatin hydrolysates, these fractions showed $\mathrm{IC}_{50}$ values of 0.04 and $0.15 \mathrm{mg}$ as peptide fraction $\mathrm{ml}^{-1}$. The finding of a higher ACE inhibition after pepsin hydrolysis than after pancreatin hydrolysis (Ugenigwe et al., 2009a) was the same as in this study. It is not possible to compare the values of $\mathrm{IC}_{50}$ because of different calculation bases; however, the peptide fraction from the pepsin hydrolyzed soluble dietary fiber fraction may express a high ACE inhibition if purified further. The soluble dietary fiber fraction in this study includes $57 \%$ carbohydrate and $32 \%$ protein, this protein was decomposed to a peptide exhibiting an ACE inhibitory activity. It is assumed that these hydroxycinnamic acids and the hydrolyzed protein (peptide) effectively inhibited ACE.

The lipoxygenase (LOX) inhibitory activity of linseed fractions and their hydrolysates is shown in Fig. 3 (bottom). No inhibition was observed with the original linseed fractions; however, enzymatic hydrolysis increased LOX inhibitory activity. Pancreatin hydrolysate of the acid-soluble fraction showed LOX inhibitory activity with an $\mathrm{IC}_{50}$ of 0.08 $\mathrm{mg} \mathrm{ml}^{-1}$, which was significantly higher than those of the other fractions. LOX was inhibited by ascorbic acid with an $\mathrm{IC}_{50}$ of $0.056 \mu \mathrm{g} \mathrm{ml}^{-1}$. There was no relationship between LOX inhibitory activity and hydroxycinnamic acid content, as shown in Table 5. Therefore, this inhibitory effect may have been caused by other factors such as peptides or amino acids released from the protein part of the fraction. The fraction that effectively inhibited ACE did not effectively inhibit LOX. This suggests that the inhibition sites for ACE and LOX in these fractions are different. Further experiments, including kinetic research, may support this assumption.

The DPPH radical scavenging activity of linseed fractions and their hydrolysates is shown in Fig. 4 (top). DPPH was scavenged by pepsin hydrolysate and pancreatin hydrolysate of soluble dietary fiber with $\mathrm{ED}_{50}$ values of 0.23 and $0.43 \mathrm{mg} \mathrm{ml}^{-1}$, whereas ascorbic acid and trolox showed $\mathrm{ED}_{50}$ values of 1.39 and $4.72 \mu \mathrm{g} \mathrm{ml}^{-1}$, respectively. The copper reducing capacities of linseed fractions and their hydrolysates are shown in Fig. 4 (bottom). Copper was reduced by pepsin hydrolysate and pancreatin hydrolysate of soluble dietary fiber with trolox equivalent values of 140 and $147 \mathrm{nmol}$ $\mathrm{mg}^{-1}$, respectively. The highest DPPH radical scavenging and copper reducing activities were both obtained from the same pepsin and pancreatin hydrolysates of soluble dietary fiber.
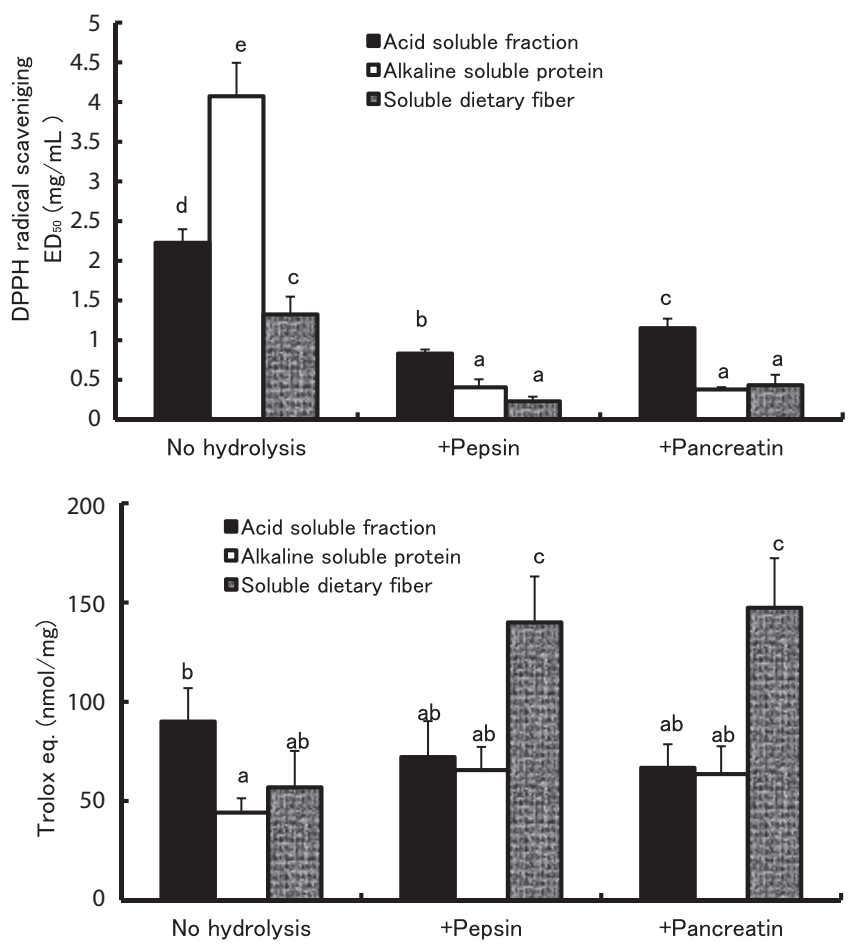

Fig. 4. DPPH radical scavenging (top) and cupper reducing (bottom) activities of linseed fractions and its hydrolysates. Different letters within the same figure indicate significant differences at $\mathrm{p}<$ 0.05 . 
When results were calculated on a mg trolox equivalent basis, the DPPH radical scavenging activity and copper reducing capacity of pepsin hydrolysate and pancreatin hydrolysate of the soluble dietary fiber fraction were 20.5 and 11.0 $\mathrm{mg}$ trolox eq. $\mathrm{g}^{-1}$ for DPPH, and 35.0 and $36.8 \mathrm{mg}$ trolox eq. $\mathrm{g}^{-1}$ for copper reduction, respectively. This comparison indicates that soluble dietary fiber hydrolysates reduced copper more effectively than DPPH radical scavenging. Hydrolysates may express antioxidant capacity mainly by reducing power. Hu et al. (2007) reported the antioxidant activities of linseed, and they mentioned that a higher SDG content induced a more effective DPPH radical scavenging. Among our results, the SDG content in the methanolic extracts decreased as hydrolysis progressed; however, both DPPH radical scavenging and copper reducing activities were increased by hydrolysis. Udenigwe et al. (2009b) mentioned that linseed protein hydrolysate showed different radical scavenging activities depending on the hydrolysis method. The pepsin hydrolysate of linseed protein was reported to have no DPPH or hydroxyl radical scavenging activity but pancreatin hydrolysate showed a high hydroxyl radical scavenging activity. In our study, DPPH radical scavenging and copper reduction were detected after pepsin or pancreatin hydrolysis, and their activities were not significantly different between pepsin and pancreatin hydrolysis. The difference between this study and previous studies indicate that both fractionation and hydrolysis methods affect antioxidant activity.

As shown in Fig. 5 (top), all of the fractions showed sodium cholate binding capacity, and this binding capacity did not decrease following enzymatic treatment. In comparison, cholestyramine bound $56.7 \%$ of sodium cholate. As shown in Fig. 5 (bottom), sodium deoxycholate was not bound similarly to cholate. The alkaline soluble protein fraction exhibited the lowest binding activity, whereas cholestyramine bound $76.7 \%$ of deoxycholate. Hypocholesterolemic effects for flaxseed lignan have been reported (Prasad, 2005); therefore, both lignan and dietary fiber (soluble dietary fiber fraction) from flaxseed are able to bind bile acids and inhibit cholesterol accumulation in the human body. Therefore, in this in vitro experiment, the soluble dietary fiber fraction was expected to have stronger bile acid binding because of a higher dietary fiber content; however, this fraction did not exhibit a marked binding effect.

\section{Conclusions}

The fractionation and analysis results of this study led to the following conclusions: the acid-soluble fraction is useful for increasing viscosity of food, and when making soybean products with a certain viscosity, addition of the acidsoluble fraction would be useful for obtaining the desired
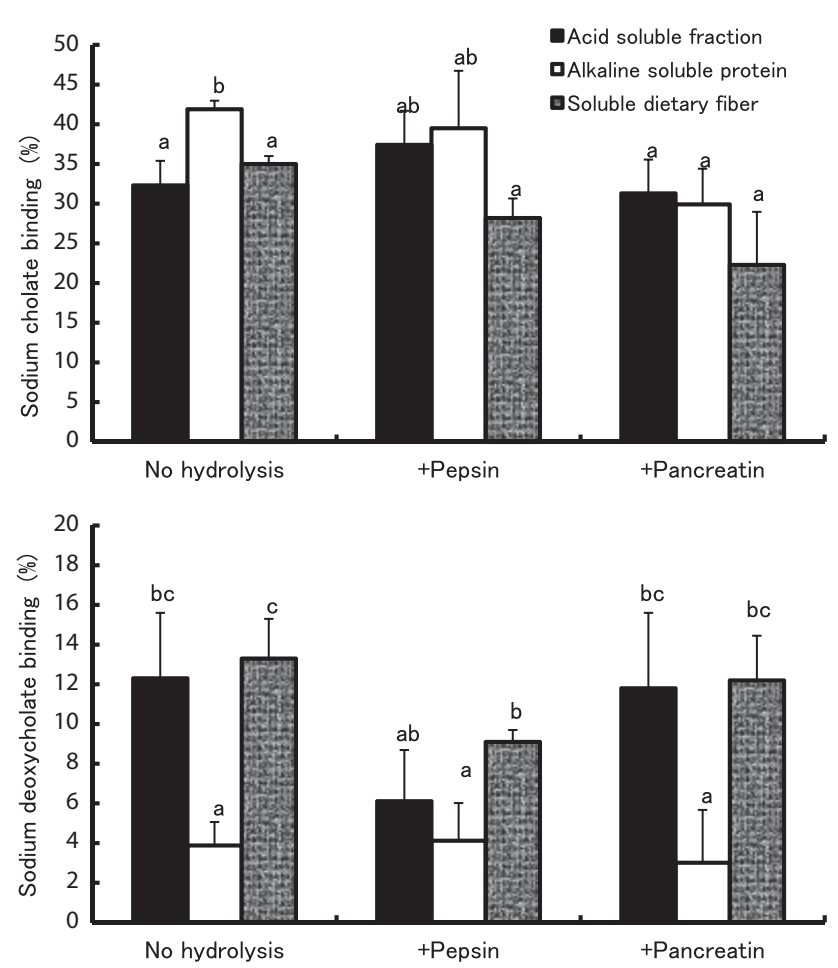

Fig. 5. Bile acid binding activities of linseed fractions and its hydrolysates. Different letters within the same figure indicate significant differences at $\mathrm{p}<0.05$.

viscosity and enhancing the LOX inhibitory effect; using a $\mathrm{pH}$-controlled process, the soluble dietary fiber fraction produced antioxidative and antihypertensive compounds with reasonable foaming activity; and the alkaline-soluble protein fraction was a concentrate of SDG, coumaric acid, and ferulic acid, which may have been responsible for the observed antioxidative effects.

Acknowledgements This research project was partly supported by the German Ministry of Economics and Technology (via AiF), the FEI (Forschungskreis der Ernährungsindustrie e.V., Bonn), Project AiF 14447 BG, and the Iijima Memorial Foundation for the Promotion of Food Science and Technology. We would also like to thank the Tokyo University of Marine Science and Technology for supporting our international collaboration work.

\section{References}

American Association of Cereal Chemists (AACC). (2000). 46.Nitrogen 46-23. Nitrogen Solubility Index. In Approved Methods of the AACC, (10th ed.); St. Paul, MN. AACC.

American Association of Cereal Chemists (AACC). (2000). 56 Physicochemical Tests 56-20. Hydration capacity of pregelatinized cereal products. In Approved Methods of the AACC, (10th ed.) St. Paul, MN, AACC.

American Oil Chemists' Society (AOCS). (1998). AOCS official 
method Ba 11-65. In Official Methods on Recommended Practices of the AOCS. (5th ed.), Champaign, IL., AOCS.

Blumenkrantz, N. and Asboe-Hansen, G. (1973). New method for quantitative determination of uronic acids. Anal. Biochem., 54, 484-489.

Chung, M.W.Y., Lei, B. and Li-Chan, E.C.Y. (2005). Isolation and structural characterization of the major protein fraction from NorMan flaxseed (Linum usitatissimum L.). Food Chemistry, 90, 271-279.

Cui, W., Mazza, G., Oomah, B.D. and Biliaderis, C.G. (1994). Optimization of an aqueous extraction process for flaxseed gum by response surface methodology. LWT-Food Sci. Tech., 27, 363369.

Cushman, D.W. and Cheung, H.S. (1971). Spectrometric assay and properties of the angiotensin-converting enzyme of rabbit lung. Biochem. Pharmacol., 20, 1637-1648.

Dubois, M., Gilles, K.A., Hamilton, J.K., Rebers, P.A. and Smith, F. (1956). Colorimetric method for determination of sugar and related substance. Anal. Chem., 28, 350-356.

Eliasson, C., Kamal-Eldin, A., Andersson, R., and Aman, P. (2003). High-performance liquid chromatographic analysis of secoisolariciresinol diglucoside and hydroxycinnamic acid glucosides in flaxseed by alkaline extraction. J. Chromatogr. A, 1012, 141-149.

Fedeniuk, R. and Biliaderis, C.G. (1994). Composition and physicochemical properties of linseed (Linum usitatissimum L.) mucilage. J. Agric. Food Chem., 42, 240-247.

Hall III, C., Tulbek, M.C. and Xu, Y. (2006). In Taylor, S. (ed.), Advances in Food and Nutrition Research, Vol. 51, Academic Press, San Diego, CA, USA, pp. 1-97.

Hernández-Ledesma, B., Martin-Álvarez, P.J. and Puero, E. (2003). Assessment of the spectrophotometric method for determination of angiotensin-converting-enzyme activity: Influence of the inhibition type. J. Agric. Food Chem., 51, 4175-4179.

Hu. C., Yuan, Y.V. and Kitts, D.D. (2007). Antioxidant activities of the flaxseed lignan secoisolariciresinol diglucoside, its aglycone secoisolariciresinol and the mammalian lignans enterodiol and enterolactone in vitro. Food Chem. Toxicol., 45, 2219-2227.

Lebensmittel- und Bedarfsgegenstände-Gesetz, Methodenbeschreibungen. 1995; Amtliche Sammlung von Untersuchungsmethoden nach $\S 35$ LMBG.

Ludwig, I., Ludwig, E. and Pingel, B. (1989). Eine Mikromethode zur Bestimmung der Fettbindkapazitaet. Nahrung/Food, 33(1), s99.

Morr, C.V., German, B., Kinsella, J.E., Regenstein, J.M., Van Buren, J.P., Kilara, A., Lewis, B.A. and Mangino, M.E. (1985). A Collaborative study to develop a standardized food protein solubility procedure. J. Food Sci., 50, 1715-1718.

Müller, K., Eisner, P., Yoshie-Stark, Y., Nakada, R. and Kirchhoff, E. (2010). Functional properties and chemical composition of fractionated brown and yellow linseed meal (Linum ustatissimum L.).
J. Food Engineer, 98, 453-460.

Mullally, M.M., Meisel, H. and FitzGerald, R.J. (1997). Angiotensin-I-converting enzyme inhibitory activities of gastric and pancreatic proteinase digests of whey proteins. Int. Dairy J., 7, 299303.

Oomah, B.D. and Mazza, G. (1993). Processing of flaxseed meal: Effect of solvent extraction on physicochemical characteristics. LWT-Food Sci. Tech., 26, 312-317.

Oomah B.D. and Mazza, G. (1998). Fractionation of flaxseed with an batch dehuller. Industr. Crops Products, 9, 19-27.

Pihlanto-Leppälä, A., Rokka, T., and Korhonen, H. (1998). Angiotensin I converting enzyme inhibitory peptides derived bovine milk proteins. Int. Dairy J., 8, 325-331.

Prasad, K. (2005). Hypocholesterolemic and antiatherosclerotic effect of lignan complex isolated from flaxseed. Atherosclerosis, 179, 269-275.

Southgate, D.A.T. (1991). In Barking, 2nd ed, Determination of food carbohydrates, Elsevier Science Publisher, Ltd., UK, 1991.

Steel, R.G.D. and Torrie, J.H., (1980). Principles and procedures of statistics: A biometrical approach (2nd ed.), McGraw Hill, New York.

Strandas, C., Kamal-Eldin, A., Andersson, R. and Aman, P. (2008). Composition and properties of flaxseed phenolic oligomers. Food Chemistry, 110, 106-112.

Udenigwe, C.C., Lin, Y-S., Hou, W-C. and Aluko, R.E. (2009a). Kinetics of the inhibition of rennin and angiotensin I-converting enzyme by flaxseed protein hydrolysate fractions. J. Funct. Foods, 1 , 199-207.

Udenigwe, C.C., Lu, Y-L., Han, C-H., Hou, W-C. and Aluko, R.E. (2009b). Flaxseed protein-derived peptide fractions: Antioxidant properties and inhibition of lipopolysaccharide-induced nitric oxide production in murine macrophages. Food Chemistry, 116, 277-284.

Wanasundara, P.K.J.P.D. and Shahidi, F. (1997). Functional properties of acylated flax protein isolates. J. Agric. Food Chem., 45, 2431-2441.

Wang, W., Onnagawa, M., Yoshie, Y., and Suzuki, T. (2001). Binding of bile salts to soluble and insoluble dietary fibers of seaweeds. Fisheries Sci., 67, 1169-1173.

Warrand, J., Michaud, P., Picton, L., Muller, G., Courtois, B., Ralanirina, R., and Courtois, J. (2003). Large-scale purification of water soluble polysaccharides from flaxseeds mucilage, and isolation of a new anionic polymer. Chromatographia, 58, 331335.

Westcott, N.D. and Muir, A.D. (2003). Flax seed lingnan in disease prevention and health promotion. Phytochem. Rev., 2, 401-417.

Yoshie-Stark, Y., Bez, J., Wada, Y., and Wäsche, A. (2004). Functional properties, lipoxygenase activity and health aspects of Lupinus albus protein isolates. J. Agric. Food Chem., 52, 76817689. 
Yoshie-Stark, Y., Tsukamoto, M., Futagawa, K., Kubota, M., and Ogushi, M. (2009). Bioactivities of surimi from southern blue whiting prepared by different ways. Food Chemistry, 113, 47-52.
Yoshie-Stark, Y. and Wäsche, A. (2004). In vitro binding of bile acids by lupin protein isolates and their hydrolysates. Food Chemistry, 88, 179-184. 